\title{
ENI DE MESQUITA SAMARA: PESQUISADORA DE VANGUARDA
}

\author{
*Vera Lucia Amaral Ferlini
}

Se é dolorosa a ausência da amiga pessoal, da colega atuante e da parceira em tantas empreitadas, ao relembrar Eni de Mesquita Samara e percorrer sua trajetória, sua figura como pesquisadora de vanguarda, há muito dedicada aos estudos sobre as mulheres, emerge como exemplo e incentivo.

Desde I97I, instrutora voluntária dos cursos de História do Brasil Colonial, em I977, por concurso público, tornou-se professora do Departamento de História da FFLCH-USP. Havia defendido, em 1975, um primoroso mestrado, O papel do agregado na região de Itu (1780-1830), que se tornaria obra de referência no estudo do papel das populações livres em economias escravistas.

Já à época destacava-se sua sensibilidade para temas inovadores. O trabalho, publicado em edição especial dos Anais do Museu Paulista, ainda nos anos de I970, ganharia versão definitiva, em edição da Edusp de 2005, sob o título Lavoura Canavieira, Trabalho Livre e Cotidiano: Itu, 1780-1830. Estudo pioneiro, descortinou a existência dessas populações, no âmbito da florescente produção açucareira do período, dando concretude às discussões sobre o papel desse grupo e suas relações com os grandes proprietários.

Em sua pesquisa, vasculhou inventários e testamentos, que delineavam a estrutura familiar das elites escravistas e sugeriram sua pesquisa de doutorado, defendida em I980, A família na sociedade paulista do século XIX, publicada, em I989 sob o título As mulheres, o poder e a família em São Paulo. Em ambos os trabalhos, a pesquisadora minuciosa valeu-se do instrumental da Demografia Histórica, para traçar magníficos painéis da economia e da sociedade de São Paulo.

Nos anos de I980, dois temas se cruzaram em seus estudos. De um lado, resultado da análise das estruturas familiares da sociedade paulista no século XIX, as mulheres. De outro, a América Latina, por sua participação na formação e implantação no GEDHAL (Centro de Estudos de Demografia Histórica da América Latina).

A partir de I99I, desenvolveu junto ao Projeto Integrado CNPq Economias exportadoras e formação do mercado de trabalho na América Latina, importante pesquisa comparativa, publicada em periódicos e obras de conjunto, no Brasil, na Espanha e nos Estados Unidos. Esses estudos tiveram continuidade com Gênero, identidade e representações na América Latina do século XIX, também financiado pelo GNPq, até $200 \mathrm{I}$.

Com Mulheres proprietárias e chefes de família no Brasil, voltou a estudar as mulheres em várias partes do Brasil, do Período Colonial ao início do século XX. Além do perfil demográfico dessas mulheres (idade, estado civil, condição, raça e ocupação) e os tipos de organizações familiares que lideravam, destacou sua participação no processo de circulação de riquezas e estruturação do poder local, com base em farta documentação, constituída por: censos, recenseamentos, inventários e testamentos. A pesquisa, que se desenvolveu por seis anos, resultou em base de dados, à disposição dos pesquisadores, através do CEDHAL.

Em 2007, após ter delineado o perfil de mulheres proprietárias na produção açucareira paulista dos séculos XVIII e XIX, Eni iniciou novo projeto sobre mulheres na economia cafeeira do século XIX: Senhoras do Café: gênero, família e riqueza em São Paulo (1836-1872). Nele, dedicou-se ao

\footnotetext{
* Professora titular do Departamento de História da Faculdade de Filosofia, Letras e Ciências Humanas (FFLCH) da Universidade de São Paulo e diretora do Monumento Nacional Ruínas Engenho São Jorge dos Erasmos.
} 
estudo do patrimônio das mulheres paulistas, proprietárias de bens e de negócios no período de I836 a I872, procurando entender o processo de circulação da riqueza na cidade com o desenvolvimento propiciado pelo café.

No decorrer da pesquisa, mesmo sob tratamento, seu entusiasmo e sua sensibilidade para novos temas e novas abordagens não diminuiu. Entrevistada pela Revista de História, da Biblioteca Nacional, em janeiro de 2010, contava que nesse projeto havia descoberto os preciosos inventários do brigadeiro Manoel Rodrigues Jordão e de sua esposa, Gertrudes Galvão de Oliveira Lacerda. O estudo desse caso permitiria entender as relações matrimoniais e patrimoniais em famílias de elite, já que em suas pesquisas anteriores dera mais ênfase a mulheres trabalhadoras. Suas palavras retratam a paixão e ousadia intelectual que é seu legado:

Esse é o material das minhas próximas pesquisas. Se der tempo, quero estudar os filhos para saber o que aconteceu com eles [...]. Preciso contar essa história. [...] O historiador precisa descobrir temas novos. Por isso fiquei tão feliz quando encontrei essa documentação. [...] Eu precisava desse novo entusiasmo. Eu queria contar outras histórias [I].

\section{REFERÊNCIA BIBLIOGRÁFICA}

[I] SAMARA, Eni de Mesquita. Eni de Mesquita Samara: "Não é o gênero que importa, mas a qualificação da pessoa”. Revista de História da Biblioteca Nacional. Rio de Janeiro, n. 64, jan. 201 I. Entrevista concedida a Rodrigo Elias e Nelson Cantarino. Disponível em: <http://www.revistadehistoria.com.br/secao/entrevista/eni-samara-mesquita>. Acesso em: [20 out. 20II?]. 